\title{
CAPITAL MOVEMENTS AND INVESTMENT IN THE EUROPEAN COMMUNITIES
}

\author{
Hermann J. Abs*
}

\section{INTRODUCTION}

So far, it has been difficult to obtain an exact idea of international capital movements within the European Economic Community (E.E.C.) owing to the lack of accurate statistics permitting comparisons among the various countries. It is, therefore, impracticable to furnish reliable information on the extent to which the organization of the E.E.C. has had had an effect on the capital imports and exports of the partners to the Treaty of Rome, and to forecast what the future will hold in store. However, it may be taken for granted that any intensification of capital transactions within the E.E.C. will conform to the degree in which the functioning of a Common Market in the fullest sense of the word is accomplished, meaning a market characterized by generous freedom of movement in all transactions relating to persons, money, goods, and capital, and by close coordination of national economic and financial policies capable of functioning satisfactorily in difficult situations.

Nobody seems to be able to tell exactly to what degree it will be possible to realize this ideal, although past experiences inspire a fair measure of confidence. During the last few years, financial stability has been consolidated even in those countries of the E.E.C. that a few years previously, from the viewpoint of financial policy and capital transactions, had to some extent still been "problem children." Quite generally, considerable progress has been made in removing impediments to competition.

In the event that the realization of the Treaty of Rome-in accordance with the spirit as much as the letter-is really accomplished along liberal lines of thought, it should be possible to anticipate a favorable development of the contribution that the countries bound together in the E.E.C. can make towards world-wide capital transactions. Freedom of movement between the E.E.C. and third-party countries must, in the writer's personal view, be looked upon as an essential sequel to a liberal nonprotectionist order within the E.E.C.; it should, in fact, be a matter of course. Again, the fact that the regional structure of foreign trade among the E.E.C. countries, especially in the Federal Republic of Germany and the Benelux countries, is characterized by world-wide interramification-a trend that it is important not merely to maintain, but to strengthen-affords ground for expectations that the progressive interlocking of capital within the Six will not proceed along exclusive lines. There is all the less reason to be apprehensive of the contrary result, since the European Monetary Agreement-in which, in addition to the E.E.C. coun-

* Vice-President of Board of Directors, Reconstruction Loan Corporation, Frankfurt (Main); Member, rd of Management, Deutsche Bank Aktiengesellschaft, Frankfurt (Main). 
tries, the United Kingdom, the Scandinavian countries, Switzerland, and other nations are partners-and the convertibility of currencies in general have proved a success. There thus exists a very effective link as regards currencies and capital transactions among almost all countries of western Europe and with the dollar-bloc countries.

The Commission of the E.E.C. has, in the meantime, issued directives designed to accelerate the liberalization of capital transactions among the E.E.C. The success of these measures remains to be seen. In any case, they are in line with the conception communicated beforehand. This also implies that they will certainly not create fresh impediments to capital transactions between the Six and the other countries.

\section{I}

Private Capital Transactions within the E.E.C.

In endeavoring to convey a general idea of capital transactions within the E.E.C., the writer feels that one ought to start out with private capital exports and imports-and not only because in terms of quantity they are first in significance. If we are determined to maintain and to promote along sound lines an order founded on the notion of private property-which includes means of production-and the principle of fair competition on a national and international scale, we shall have to admit that if commercial capital transactions are to stand any real chance, they must be accorded priority over those accomplished by the government. The fact that, as things stand today, foreign investments cannot be organized entirely on a commercial basis, especially in the so-called development countries and areas, is a different matter, with which we are not immediately concerned at this juncture.

\section{A. Increasing Share of E.E.C. Countries in German Private Capital Exports}

As has already been observed, there are, so far, no accurate figures at hand regarding the development of capital transactions as a whole within the E.E.C. However, it may be of interest to analyze the capital movements relating to the E.E.C. for an individual member country for which some records are available-for example, the Federal Republic of Germany. Of German private long-term net capital investments abroad, totalling DM r,400,000,000 in $1960, \mathrm{DM}_{526,000,000 \text {, or }}$ somewhat more than one-third, went to E.E.C. countries; in 1958, the corresponding figure had been roughly twenty per cent. The European Free Trade Area (E.F.T.A.) in Ig6o took up twenty-five per cent of private long-term capital investments abroad, against twenty-nine per cent in 1958 .

Now, it would obviously be unwise to deduce too much for the long run from the experiences of a few years. Nevertheless, the fact stands out that cooperation between interested German quarters and foreign bourses and banks within the E.E.C. area, has developed in a particularly impressive manner. In recent years, a very large part of the capital investments of German citizens in foreign paper related to securities domiciled in other E.E.C. countries. On an over-all view, private long-term 
net capital exports in $195^{8}$ comprised just under one-quarter of portfolio investments; in Ig60, this share had reached slightly less than fifty per cent. Last year, over onehalf of all foreign securities bought concerned issues in E.E.O. countries, while between eleven and twenty-four per cent concerned issues in the United States and the E.F.T.A. countries respectively. In part-particularly as far as issues of the E.E.C. are concerned-this may be due to foreign securities being acquired by firms seeking interests in other countries, but there is no doubt that the bulk is accounted for by the purchase of foreign paper by individual German investors. Due to currency speculation and changes in the international structure of interest rates, the long-term net capital exports of the Federal Republic of Germany-which in I959 had amounted to almost DM $4,000,000,000-$ were in the past year reduced to DM 480,000,000 (excluding donations, restitution payments, etc.). Only to an insignificant degree was this decline the result of diminished German transfers to foreign countries; on the other hand, the extraordinary increase of foreign capital investment in the Federal Republic was of unusually great importance.

\section{B. Direct Investments within the Community}

As far as the writer can see, it is unlikely that any decisive regional shifts have taken place in direct investments on the part of business enterprises in recent years. Actually, there is, on the face of it, for many business enterprises within the Common Market little reason to establish production plants of their own in other E.E.C. countries. After all, the reduction of customs duties and the removal of other trade impediments offer ample opportunities to supply the entire E.E.C. from each national production base without any fear of discriminating restrictions on competition. Exceptions may apply in cases where the cost of transport is relatively great by comparison with the value of the product. Also, it will probably frequently be necessary to set up individual sales organizations throughout the E.E.C.

However that may be in individual instances, financial interramification between the national economies of E.E.C. is steadily on the rise. We must also envisage an increasing exchange of licences, patents, and the like, which likewise entail financial consequences. Incidentally, international investment trusts have achieved considerable popularity both in Germany and other E.E.C. countries, the securities of the latter countries being accorded preference by the trusts.

\section{II}

\section{Government-controlled Capital Transactions in E.E.C.}

Government-controlled capital transactions within E.E.C. are primarily governed by customary international principles. In this connection, mention must be made in particular of government contributions towards export financing. In the Federal Republic of Germany, as in other countries, this consists principally in the granting of government guarantees and assurances in favor of medium-term export credits. As a general principle, the writer is inclined to think that the policy of the 
E.E.C. should be as prudent as in other matters-meaning that, under all circumstances, a revival of unsound competition among governments in granting financial assistance to regular exports of durable goods to be financed over medium and: longer terms must be avoided.

Special institutions serving government-controlled capital transactions within the E.E.C. are, in particular, the European Investment Bank and the E.E.C. Development Fund.

\section{A. European Investment Bank}

It is the purpose of the European Investment Bank primarily to contribute towards the opening-up of less-developed areas within the Common Market. In addition, its tasks include the financing of production change-over projects, which may become necessary in the course of the continuing realization of the E.E.C., and: participation in other projects of common interest where financing requirements exceed the capacities of the various member countries. The Bank was set up with. a capital of $\$ \mathrm{I}, 000,000,000$, of which twenty-five per cent had to be paid in initially in installments. The balance is considered guarantee capital, to be called up when: required. The various E.E.C. countries share in the capital of the Investment Bank in the following proportions:

$\begin{array}{lr}\text { Germany } & \$ 300,000,000 \\ \text { France } & 300,000,000 \\ \text { Italy } & 240,000,000 \\ \text { Belgium } & 86,500,000 \\ \text { Netherlands } & 7 \mathrm{I}, 500,000 \\ \text { Luxembourg } & 2,000,000\end{array}$

In addition to responding to requests for special loans on the part of the member countries, the Bank is also authorized to make loans on the international capital markets. It is explicitly provided that in its financing principles, the Bank is. to model its activities on those of the World Bank, with which it proposes to. cooperate closely.

In certain respects, it has become apparent during the past few years that thereis less dependence on the Bank than had been generally anticipated before the conclusion of the Treaty of Rome. Whenever investment projects within the E.E.C. failed to obtain the necessary financing by commercial credits or by the aid of the respective national government, international syndicates, and also occasionally the World Bank, have offered favorable financing possibilities.

So far, the granting of loans by the Bank has been kept within comparatively narrow limits. During the first three business years, it authorized a total of twelve loans in the aggregate amount of $\$ 93,500,000$ of which $\$ 6 \mathrm{x}, 000,000$ related to projects in Italy and just under $\$ 26,000,000$ to projects in France. Although as much as $\$ 250,000,000$ had been paid in on the capital by the end of last year, the payments 
actually made to loan recipients amounted to a total of $\$ 33,000,000$. The facilities offered by the Bank are thus at present far from being fully utilized.

Nevertheless, it seems possible that in the long run, the Bank should do more business than it has to date. Quite apart from the fact that every credit institution requires time to set up in business on a sound basis, it seems likely that as the Treaty of Rome comes nearer to realization, there will be an increasing demand for investments to permit better structural adjustment of specific industries and regions. The extent, however, to which this will involve a greater demand for public funds will presumably be largely dependent upon the development of international business activities and the capital markets.

\section{B. E.E.C. Development Fund}

The E.E.C. Development Fund was formed to contribute towards furthering the social and economic development of those overseas countries and territories that are associated with the Common Market. Under the terms of article 131 of the E.E.C. Treaty, they include such non-European countries and territories as maintain particular relations with Belgium, France, Italy, and the Netherlands. The general tendency is to afford an opportunity of association to those overseas countries that are no longer by international law linked with one of the European partners of E.E.C. This would seem to apply in particular to the African territories that have now become politically independent. By the end of 1962 , the E.E.C. partners will have paid \$58r,000,000 into the Fund, of which $\$ 200,000,000$ will come each from France and the Federal Republic of Germany. The Fund, like the Investment Bank, could at first make final decisions on comparatively few projects. At the end of summer, Ig6x, financing contracts for only seventeen projects in the amount of around $\$ 10,000,000$ had been firmly agreed upon. In the meantime, however, the Fund has received higher capital allotments. At the end of April I96r, the approved financial appropriations amounted to $\$ 148,000,000$.

The projects to be financed out of the Fund are not, as a general rule, scheduled to produce any yield, although their promotion is to be in the interest of the overseas territories and of the members of the E.E.C. Only "genuine economic assistance matters" are envisaged. Doubtlessly, the success of financial aid granted out of the Fund will essentially depend upon whether efforts to establish the necessary political and economic conditions for a steady, progressive opening-up of the regions in question are successful. If the Fund is forced to rely on its own resources-i.e., if its grants are not supplemented by capital invested on a commerical basis-the results can hardly be expected to prove adequate nor to have any lasting effect.

In recent decades, private capital exports from the Federal Republic of Germany to Africa have been negligible. During the years following I950, the total was no more than DM I80,000,000, which is slightly over six per cent of the over-all foreign investments of German enterprises (direct investments). This low share reflects the fact that since World War I, German trade and industry has taken compara- 
tively little interest in Africa and, indeed, was not very often offered opportunities to do so. At the same time, it is indicative of the fact that German businessmen capable of investing money abroad and willing to do so have hitherto considered activities in other parts of the world to be more rewarding.

\section{III}

Investments of Non-Member Countries within the E.E.C.

The formation of a Common Market on the European continent naturally has a great attraction for foreign capital. By the aid of its own production plants and sales agencies within the Market, or by acquiring participations there, even an enterprise domiciled outside the E.E.C. may enjoy the advantages that accrue from association with that economic area. For Americans, the still comparatively low labor costs form a supplementary incentive. The noticeable lack of skilled labor in the European industrial centers is, however, often an obstacle in the way of commissioning new manufacturing plants that is not always easy to surmount.

Capital coming in from non-member countries is today enabled to operate in the E.E.C. area under practically the same conditions as domestic capital, although there are still differences within the various countries. The Federal Republic of Germany is among those countries where foreign-exchange control to all intents and purposes no longer exists. In view of the favorable balance-of-payments situation with all E.E.C. countries, whose currency reserves from 1957 to I959 rose by $\$ 3,300,000,000$, it seems fair to anticipate a further improvement of the chances for investments by foreigners even in the countries that in recent years still had to put up with foreign-exchange difficulties.

Until a short time ago, the United Kingdom absorbed the bulk of the United States capital flowing to Europe, but since the beginning of 1959, the countries of the Common Market have been gaining in popularity as an objective of American. investments. In the Federal Republic of Germany, too, foreign enterprises have, during the past two years, acquired interests in considerably greater measure than in the past. Here, again, it is American firms that account for the principal share. It is a noteworthy fact that United States capital no longer concentrates in the same measure as in former times on specific industrial fields (such as the mineral oil industry and processing industry), but has been turning its attention to a wider range of activities, including chemistry, agricultural machinery, the rubber-processing industry, the paper industry, the foodstuffs industry, and others. Aside from the fact that West Germany will increase her capital exports-above all, in consideration of the capital requirements of development countries-she should remain a relatively significant capital importing nation.

A most important question for any investor, whether German or foreign, is whether in the foreseeable future there will be an amalgamation of some kind between the E.E.C. and E.F.T.A. Producers and exporters anxious to safeguard their sales in one or both of the two regions will, if they are sceptical as regards 
chances of a merger, tend to establish production plants or branches or to seek participations in both. But double-investment projects of this kind may turn out to be misdirected in the event that an effective economic association embracing the whole of western Europe does come about. The fact that this is looked upon by the West German business community and public opinion in general as a task to be realized at the earliest possible date is something that should be stressed, although at the same time, it should be emphasized that European economic integration is far from being envisaged as a means to insure segregation from other continents. On the contrary, it is seen as a contribution to the progressive intensification of goods and capital transactions on a world-wide scale.

Whatever the future may have in store for us, the writer is firmly convinced that the European, and more particularly the West German, contribution to international capital transactions will remain characterized by a world-embracing outlook and that the share of a number of non-European countries in capital exports from Europe will become even greater. 